\title{
Pengenalan Energi Terbarukan dengan Fokus Energi Matahari kepada Siswa Sekolah Dasar dan Menengah
}

\author{
Fenny Irawati ${ }^{1}$, Fitri Dwi Kartikasari ${ }^{2}$, Elieser Tarigan ${ }^{3}$ \\ ${ }^{1}$ Prodi Biologi, Fakultas Teknobiologi, Universitas Surabaya \\ ${ }^{2}$ Prodi Teknik Informatika, Fakultas Teknik, Universitas Surabaya \\ ${ }^{3}$ Prodi Teknik Elektro, Fakultas Teknik, Universitas Surabaya \\ fenny_i@staff.ubaya.ac.id
}

\begin{abstract}
ABSTRAK
Perkembangan peradaban manusia tidak pernah lepas dari proses pemanfaatan energi. Saat ini hampir seluruh aspek kehidupan manusia memiliki ketergantungan terhadap energi. Secara umum sumber energi dikategorikan menjadi dua, yaitu tak terbarukan dan terbarukan. Pengenalan akan pentingnya energi terbarukan sebagai pengganti energi fosil perlu ditanamkan pada anak sejak dini. Akan tetapi, umumnya guru-guru di sekolah dasar maupun menengah mengalami kesulitan dalam menyampaikan materi tentang energi terbarukan secara mudah dan menarik. Permasalahan inilah yang diangkat oleh Pusat Studi Energi Terbarukan (PSET) Universitas Surabaya (Ubaya) untuk melakukan program pengabdian pada masyarakat dalam bentuk sosialisasi dan pengenalan energi terbarukan pada siswa sekolah mitra. Solusi permasalahan dilakukan dengan memberikan program pengenalan energi terbarukan kepada mitra pengabdian. Metode kegiatan pengabdian adalah mengunjungi/mengundang siswa sekolah mitra untuk diberi paparan interaktif tentang energi terbarukan khususnya sel surya oleh narasumber. Setelah itu siswa diminta membuat modul peraga sel surya sederhana dan mempraktikkannya secara langsung untuk mengamati energi yang dihasilkan oleh sel surya. Pemahaman siswa dievaluasi melalui survei di akhir kegiatan. Hasil survei menunjukkan bahwa program ini dapat membantu meningkatkan pemahaman siswa akan energi terbarukan khususnya tentang sel surya. Pengetahuan dasar yang diberikan pada siswa sekolah mitra diharapkan dapat menjadi bekal pemahaman terkait program energi yang berwawasan lingkungan.
\end{abstract}

Kata kunci: energi terbarukan, siswa sekolah, sel surya

\section{ABSTRACT}

One of the aspects that affect human civilization development is how energy is managed and utilized. Most of the human life aspects depend on energy. Energy sources are generally categorized into two types, i.e., non-renewable or fossil-based energy and renewable resources. The importance of renewable energy as a substitute for fossil energy needs to be introduced and socialized to children from an early age, especially through formal education, especially in primary and secondary schools. However, it was identified that the educators in primary and secondary schools have difficulty delivering material on renewable energy in an easy and attractive manner. This situation motivated the Center for Renewable Energy Studies (PSET), University of Surabaya (Ubaya), to organize a program in the form of socialization and introduction of renewable energy to school students as apart of the university community service program. The program is carried out by providing a renewable energy introduction program to the students from some selected schools in Surabaya. The activity was taken place either at the University of Surabaya or at the school campus. The students were given an interactive exposure to renewable energy; besides, they were asked to make a simple solar photovoltaic (PV) demonstration module and practice it directly to observe the energy produced by the cells. At the end of the program, the students' understanding was evaluated through a test and questionnaire. The results show that the program could help improve the students' understanding of renewable energy, especially about how solar cells work. The basic knowledge about renewable energy provided to the school students is expected to be a provision for understanding the environmentally friendly energy resources.

Keywords: renewable energi, school students, solar photovoltaics

\section{PENDAHULUAN}

Perkembangan peradaban manusia tidak pernah lepas dari proses pemanfaatan energi.
Matahari merupakan sumber energi penting dan utama sejak awal sejarah manusia. Sejarah peradaban manusia berkaitan dengan 
perkembangan pemanfaatan energi. Bahkan kemajuan suatu negara diindikasikan dengan tingkat konsumsi energi (Tarigan, 2014). Pada jaman ini, ketergantungan manusia pada energi menyangkut pada hampir seluruh aspek kehidupan.

Secara umum sumber energi dikategorikan menjadi dua, yaitu sumber energi tak terbarukan dan sumber energi terbarukan. Sumber energi tak terbarukan adalah sumber energi yang ketersediaannya terbatas dan tidak terjadi proses pembentukan kembali di alam, ataupun proses pembentukannya memerlukan waktu yang sangat lama, sehingga jika dipakai terus-menerus kemungkinan akan habis. Contoh sumber energi tak terbarukan adalah energi fosil seperti minyak bumi, batu bara, dan gas alam. Sumber energi terbarukan adalah sumber energi yang proses pembentukannya terjadi secara berkelanjutan sehingga ketersediaannya melimpah dan tidak pernah habis. Contoh-contoh sumber energi terbarukan adalah energi matahari, energi dari biomassa, energi angin, gravitasi air, energi panas bumi, energi gelombang dan lain-lain.

Kegiatan eksploitasi dan pemakaian sumber energi dari alam untuk memenuhi kebutuhan manusia menimbulkan dampak negatif terhadap lingkungan misalnya udara dan iklim, air dan tanah (Martono, 2017). Pada proses pembakaran sumber energi fosil untuk menghasilkan energi, terbentuk juga gas-gas yang menyebabkan pencemaran udara seperti karbon dioksida (CO2), nitrogen oksida (NOx),dan sulfur dioksida (SO2). Gas-gas tersebut berkontribusi pada terjadinya hujan asam, smog dan pemanasan global (Martono, 2017; Wuebbles et al., 2017).

Pengenalan akan pentingnya energi terbarukan sebagai pengganti energi fosil perlu ditanamkan pada anak sejak pendidikan sekolah (jitunews.com, 2016; NREL, 2001; Umair Shahzad, 2017). Untuk tujuan ini, berbagai cara dapat ditempuh. Pendidikan energi terbarukan dapat dijadikan sebagai mata pelajaran tersendiri di sekolah. Dalam hal ini diperlukan kurikulum yang terstruktur. Salah satu literatur (Cholily, Inam, Utomo, \& Effendi, 2016) mengajukan pedoman penyusunan kurikulum mata pelajaran energi terbarukan untuk sekolah tingkat menengah. Selain melalui mata pelajaran khusus, program pengenalan dapat juga dilakukan dengan memasukkan topik tertentu terkait dengan mata pelajaran tertentu. Misalnya, topik energi matahari, energi angin, energi air, dan lain-lain dapat dimasukkan dalam muatan pelajaran ilmu pengetahuan alam (IPA).

Selain metode pemuatan dalam kurikulum, program pengenalan energi terbarukan dapat juga dilakukan dengan ekstrakurikuler. Terlepas dari metode yang ditempuh, program pengenalan energi terbarukan sebaiknya dilakukan dengan menyesuaikan usia dan kondisi anak didik. Modul atau alat peraga energi yang dapat dipraktikkan langsung oleh siswa akan lebih mengoptimalkan penyampaian materi (NREL, 2001).

Sekolah dasar dan menengah dipilih menjadi mitra pengabdian karena umumnya guru-guru di sekolah mitra mengalami kesulitan dalam menyampaikan materi tentang energi terbarukan secara mudah dan menarik. Permasalahan inilah yang diangkat menjadi program pengenalan energi terbarukan pada siswa sekolah baik di tingkat dasar maupun menengah. Tujuan dari program ini adalah untuk membekali dan menambah wawasan siswa sekolah tentang pentingnya energi terbarukan serta memahami secara garis besar potensi energi surya serta potensinya untuk diubah menjadi energi listrik.

Pusat Studi Energi Terbarukan (PSET) Universitas Surabaya (Ubaya) merupakan salah satu unit yang melakukan fokus penelitian dan kajian di bidang energi terbarukan, termasuk program pengabdian pada masyarakat melalui pengenalan energi terbarukan untuk siswa sekolah, termasuk siswa sekolah dasar dan menengah. Program serupa telah dilakukan di berbagai tempat baik dalam maupun luar negeri (climatecentral.org, 2019; EIA, 2016; jitunews.com, 2016; kids.kiddle.co, n.d.; NREL, 2001; Wuebbles et al., 2017).

Solusi permasalahan dilakukan dengan memberikan program pengenalan energi terbarukan tentang sel surya kepada mitra pengabdian. Metode kegiatan pengabdian adalah mengunjungi atau mengundang siswa sekolah mitra untuk diberi paparan interaktif tentang energi terbarukan khususnya sel surya oleh narasumber. Setelah itu siswa diminta membuat modul peraga sel surya sederhana dan mempraktikkannya secara langsung untuk mengamati energi yang dihasilkan oleh sel surya. Pemahaman siswa dievaluasi dengan sejumlah pertanyaan terkait melalui survei yang dilakukan di akhir kegiatan.

\section{METODE KEGIATAN}

Objek kegiatan pengabdian ini adalah sosialisasi pengenalan energi terbarukan khususnya tentang sel surya bagi siswa sekolah 
mitra. Kegiatan ini telah dilakukan kepada siswa sekolah dasar maupun menengah dari beberapa sekolah yang berbeda antara lain SD Cita Hati Surabaya, SD Kristen LOGOS Surabaya, SMP Laboratorium Surabaya, SMPN 39 Surabaya, SMP-SMA Cita Hati Surabaya dan SMA Citra Berkat Surabaya. Kegiatan ini dilakukan di sekolah mitra ataupun di gedung PSET Ubaya berdasarkan kesepakatan dengan pihak mitra. Pesertanya bervariasi mulai dari siswa kelas 3 SD sampai dengan kelas 3 SMA. Setiap kegiatan diikuti oleh kurang lebih 30 siswa dengan beberapa guru pendamping. Pelaksanaan kegiatan ini melibatkan 1 narasumber, 4 fasilitator dan 4 mahasiswa sebagai kakak pendamping kelompok.

Adapun bentuk kegiatan yang dilakukan untuk mengenalkan energi terbarukan kepada siswa sekolah mitra merupakan perpaduan antara metode klasikal (ceramah, diskusi, peragaan alat) untuk memberikan dasar pengetahuan tentang energi terbarukan khususnya sistem pembangkit listrik tenaga surya dan praktikum untuk memberi pengalaman belajar langsung tentang materi yang telah disampaikan sebelumnya. Gambaran detil bentuk kegiatan dapat dilihat pada Tabel 1 . Materi presentasi disusun dengan visualisasi yang menarik serta didukung dengan peragaan alat bantu pembelajaran yang menyerupai wujud aslinya. Presentasi dilakukan secara interaktif untuk menstimulasi rasa ingin tahu siswa yang selanjutnya akan dipenuhi pada sesi praktikum.

Tabel 1. Rancangan Kegiatan Pengenalan Energi Terbarukan

\begin{tabular}{cll}
\hline No & Aktivitas & Metode \\
\hline $\mathbf{1}$ & $\begin{array}{l}\text { Penyampaian materi } \\
\text { pengenalan energi } \\
\text { terbarukan }\end{array}$ & $\begin{array}{l}\text { Paparan } \\
\text { interaktif }\end{array}$ \\
$\mathbf{2}$ & $\begin{array}{l}\text { Peragaan alat terkait } \\
\text { energi terbarukan }\end{array}$ & Peragaan \\
$\mathbf{3}$ & $\begin{array}{l}\text { Pembuatan modul } \\
\text { energi matahari } \\
\text { sederhana }\end{array}$ & Praktikum \\
$\mathbf{4}$ & Evaluasi & $\begin{array}{l}\text { Diskusi } \\
\text { interaktif }\end{array}$ \\
\hline
\end{tabular}

Setelah itu, siswa dibagi ke dalam beberapa kelompok dan masing-masing kelompok diajak berkeliling untuk menyaksikan peragaan tentang cara kerja beberapa peralatan yang menggunakan panel surya. Selain menyaksikan peragaan, siswa juga diizinkan untuk mencoba mengoperasikan peralatan tersebut. Pada sesi ini diharapkan siswa dapat mengaitkan pengetahuan yang diperoleh dari sesi sebelumnya dengan menyaksikan langsung cara kerja beberapa peralatan yang menggunakan panel surya.

Selanjutnya, para siswa dibagi lagi ke dalam kelompok-kelompok yang masingmasing beranggotakan tiga orang dan mereka diminta untuk membuat modul peraga sederhana berdasarkan lembar kerja siswa (LKS) yang ada. Setiap kelompok diberi LKS serta satu paket alat dan bahan yang diperlukan. Setiap kelompok wajib menyusun alat dan bahan yang diterima menjadi suatu rangkaian sederhana seperti tertulis dalam LKS. Untuk memastikan rangkaian yang tersusun sudah sesuai, LKS dilengkapi dengan petunjuk pengamatan yang harus dilakukan. Sesi ini bertujuan memberi pengalaman belajar nyata kepada siswa sehingga materi yang telah didapatkan sebelumnya akan lebih diingat dan dipahami.

Sebagai bagian akhir dari kegiatan ini diberikan kuis interaktif untuk mengevaluasi pengetahuan siswa terhadap materi energi terbarukan yang telah diterima dan dipraktikkan secara langsung. Pertanyaan diajukan secara terbuka kepada seluruh siswa untuk melatih keberanian siswa mengutarakan pendapatnya. Jawaban paling cepat dan benar akan mendapat penghargaan. Seluruh rangkaian kegiatan ini berlangsung dalam waktu kurang lebih 3 jam. Rangkaian kegiatan disusun tidak hanya untuk menambah pengetahuan kognitif siswa melainkan juga memberi stimulasi motorik, melatih siswa bekerja sama, dan memicu rasa ingin tahu serta jiwa kompetitif siswa.

\section{HASIL \& PEMBAHASAN}

Sebagaimana telah direncanakan sebelumnya, program pengenalan energi terbarukan diawali dengan penyampaian materi interaktif kepada siswa sekolah mitra tentang dasar-dasar energi terbarukan dan berbagai jenis energi terbarukan yang ada oleh narasumber. Materi dibuat dengan dukungan visualisasi yang menarik beserta animasi dan cuplikan video untuk memberi gambaran nyata tentang energi secara umum dan energi terbarukan khususnya sistem pembangkit listrik tenaga surya. Beberapa contoh tampilan materi dapat dilihat pada gambar 1 .

Pada sesi peragaan, siswa sekolah mitra dibagi dalam empat kelompok. Masing-masing kelompok dengan ditemani oleh satu orang kakak pendamping diajak berkeliling untuk menyaksikan peragaan di empat pos yang 
berbeda secara bergantian. Di setiap pos ada satu orang fasilitator yang akan menjelaskan cara kerja peralatan tertentu sesuai tema. Tema masing-masing pos adalah sel surya (termasuk Pembangkit Listrik Tenaga Surya/PLTS), Pembangkit Listrik Tenaga Bayu (PLTB),
Pembangkit Listrik Tenaga Air (PLTA), dan rumah ramah lingkungan. Sesuai tema, lokasi pos dibuat bervariasi di dalam dan di luar ruangan untuk lebih memberi pengalaman nyata tentang sumber energi terbarukan (Gambar 2).
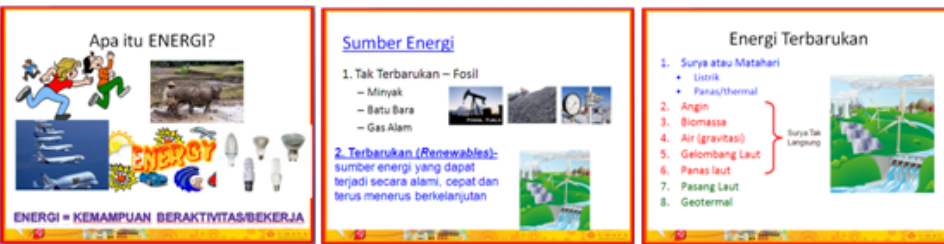

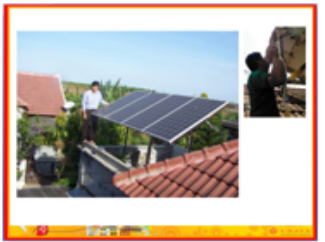

Gambar 1. Tampilan materi energi terbarukan
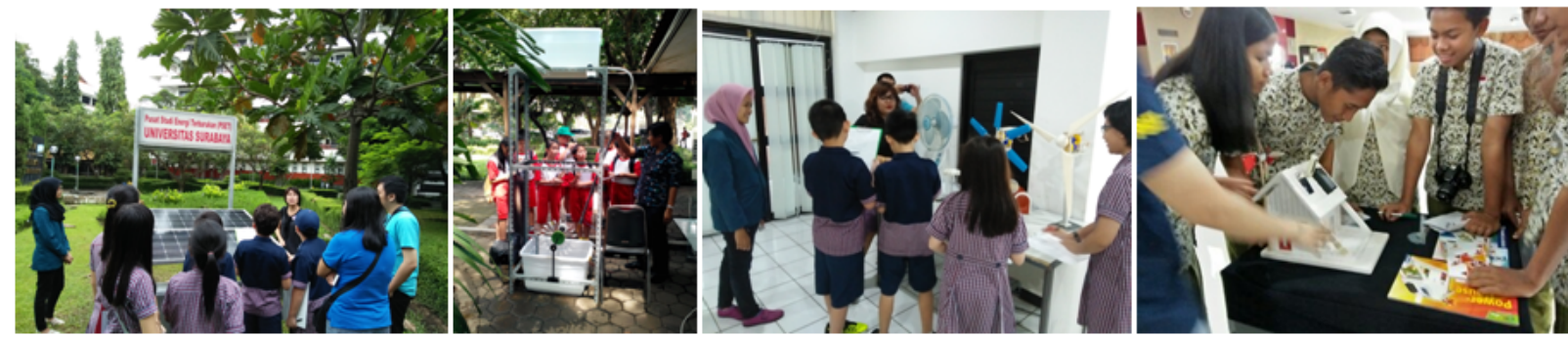

Gambar 2. Peragaan cara kerja peralatan dengan energi terbarukan

Selanjutnya, para siswa dibagi ke dalam kelompok-kelompok yang masing-masing beranggotakan tiga orang dan mereka diminta untuk membuat modul peraga sederhana berdasarkan lembar kerja siswa (LKS) yang telah disiapkan (Gambar 3). LKS sudah dilengkapi dengan panduan mengenai hal-hal yang harus diamati setelah siswa berhasil menyusun rangkaiannya. Siswa diharapkan bekerja sama menyusun rangkaian, mengamati, dan menuliskan hasil pengamatannya. Kegiatan ini tetap didampingi oleh fasilitator dan kakak pendamping.

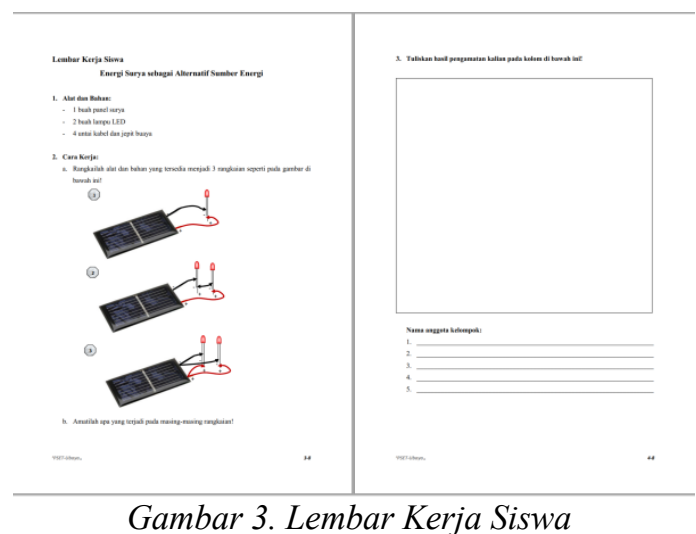

Setelah selesai praktik dan melengkapi LKS-nya, siswa berdiskusi untuk membahas fenomena yang muncul selama praktik berlangsung. Diskusi dipandu oleh narasumber dengan menggunakan berbagai media interaktif yang memicu keberanian siswa untuk mengutarakan pendapatnya secara lisan dan berkompetisi dengan teman sebayanya. Beberapa media yang digunakan sebagai bahan dan situasi diskusi terlihat pada gambar 4 dan 5 .

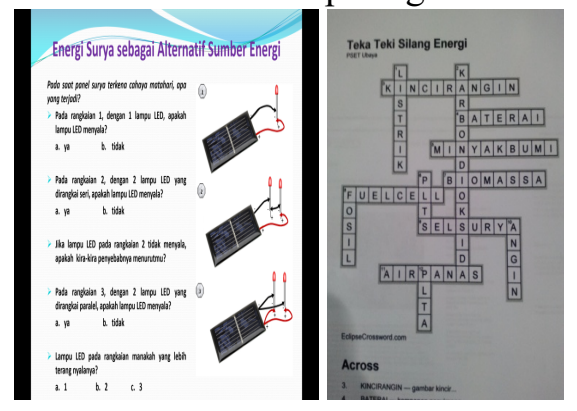

Gambar 4. Media Diskusi

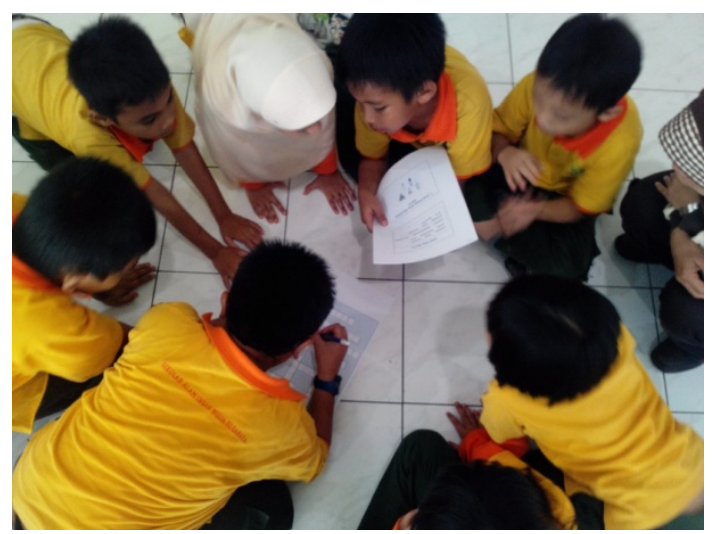

Gambar 5. Situasi diskusi 
Di akhir kegiatan siswa diminta mengisi survei sederhana untuk mengevaluasi kegiatan dan mengukur dampak kegiatan ini terhadap pemahaman siswa tentang materi energi terbarukan. Hasil survei menunjukkan bahwa rancangan materi yang dibuat sudah sesuai dengan tujuan yaitu menambah pengetahuan siswa karena disampaikan secara menarik dan mudah dipahami dan sesuai dengan alokasi waktu (Gambar 6). Peserta juga merasa terbantu dengan penggunaan alat peraga dalam kegiatan ini (Gambar 7). Selain itu, kegiatan ini juga telah berhasil menstimulasi siswa untuk terlibat belajar secara aktif dengan pemberian waktu yang cukup untuk praktik dan peragaan (Gambar 8). Berdasarkan analisis hasil survei secara umum dapat disampaikan bahwa kegiatan pengenalan energi terbarukan kepada siswa sekolah dasar maupun menengah dengan perpaduan metode klasikal dan praktik ini berhasil meningkatkan pengetahuan siswa dan memberi pengalaman belajar secara nyata sesuai tujuan.

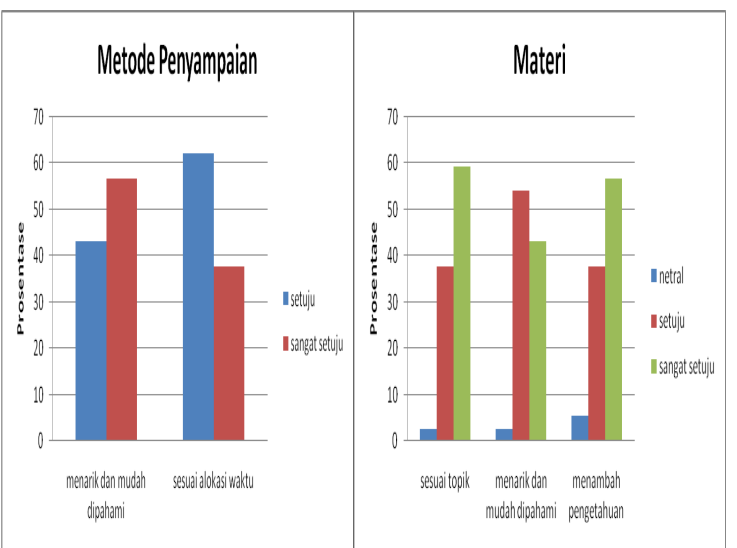

Gambar 6. Respon peserta terhadap materi dan metode penyampaian

\section{Alat Peraga membantu pemahaman}

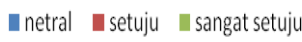

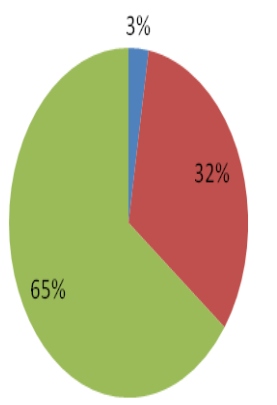

Gambar 7. Respon peserta terhadap penggunaan alat peraga

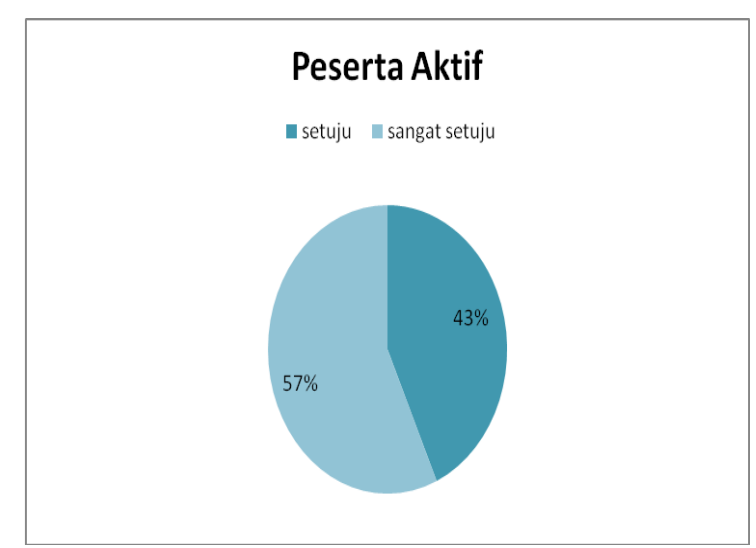

Gambar 8. Respon peserta terhadap keterlibatan belajar secara aktif

\section{KESIMPULAN \& SARAN}

Program pengabdian pada masyarakat pengenalan energi terbarukan dengan fokus energi matahari (sel surya) kepada siswa sekolah telah dilakukan bersama beberapa sekolah mitra antara lain SD Cita Hati Surabaya, SD Kristen LOGOS Surabaya, SMP Laboratorium Surabaya, SMPN 39 Surabaya, SMP-SMA Cita Hati Surabaya dan SMA Citra Berkat Surabaya. Kegiatan ini dilakukan di sekolah mitra ataupun di gedung PSET Ubaya berdasarkan kesepakatan dengan pihak mitra.

Kegiatan dilakukan dengan memberikan paparan interaktif, peragaan alat, dan pembuatan modul peraga sederhana. Pemahaman siswa dievaluasi dengan memberikan kuis. Respon siswa terhadap kegiatan ini diperoleh dengan melakukan survei berupa pemberian kuesioner pada peserta di akhir kegiatan. Hasil kuesioner menunjukkan bahwa kegiatan pengenalan energi terbarukan kepada siswa sekolah mitra dengan perpaduan metode klasikal dan praktik ini telah berhasil meningkatkan pengetahuan siswa dan memberi pengalaman belajar secara nyata sesuai tujuan. Diharapkan pengetahuan dasar yang diberikan pada siswa sekolah mitra dapat menjadi bekal bagi siswa sebagai generasi penerus bangsa terkait program energi yang berwawasan lingkungan.

\section{DAFTAR PUSTAKA}

Cholily, Y. M., Inam, A., Utomo, D. P., \& Effendi, M. M. (2016). Pedoman Implementasi Kurikulum Energi Terbarukan di SMP. Universitas Muhamadiayah Malang.

climatecentral.org. (2019). What is the relationship between the energy we use today and climate? | Climate Central. 
Retrieved December 19, 2019, from https://www.climatecentral.org/library/fa qs/what_is_the_relationship_between_the energy_we use today_and_climate

EIA. (2016). Renewab̄le - Energy Kids: U.S. Energy Information Administration (EIA). Retrieved December 19, 2019, from https://www.eia.gov/kids/energysources/renewable/

jitunews.com. (2016). Pengenalan Energi Alternatif Harus Dilakukan Sejak Dini Jitunews.com. Retrieved December 19, 2019, from https://www.jitunews.com/read/35320/pe ngenalan-energi-alternatif-harusdilakukan-sejak-dini

kids.kiddle.co. (n.d.). Renewable resource Facts for Kids. Retrieved December 19, 2019, from https://kids.kiddle.co/Renewable_resourc e

Martono. (2017). Fenomena Gas Rumah Kaca. Forum Teknologi Pudiklat Migas ESDM, $05(2)$.

NREL. (2001). Renewable Energy Activities Choices for Tomorrow Teacher 's Activity Guide for Middle Level Grades 6-8. Renewable EnergyNREL.

Tarigan, E. (2014). Fisika dan Energi Alternatif. Universitas Surabaya.

Umair Shahzad. (2017). Renewable Energy Education and Awareness at the University Level in Pakistan, (December 2015).

https://doi.org/https://www.academia.edu /32846957/Renewable_Energy_Educatio n_and_Awareness_at_the_University_Le vel_in_Pakistan

Wuebbles, D. J., Fahey, D. W., Hibbard, K. A., Dokken, D. J., Stewart, B. C., \& Maycock, T. K. (Eds.). (2017). Climate Science Special Report: Fourth National Climate Assessment, Volume I. Washington, DC. https://doi.org/10.7930/J0J964J6 